\title{
First envenomation report of the Cnidarian Physalia physalis in Indonesia
}

\author{
Tri Maharani $^{1}$, Widiastuti Widiastuti ${ }^{2}$ \\ ${ }^{1}$ National Institute of Health Research and Development, Ministry of Health, Republic of Indonesia, \\ J. Percetakan Negara No. 29, 10560 Jakarta Pusat, Indonesia \\ ${ }^{2}$ Department of Marine Science, Faculty of Marine Science and Fisheries, Udayana University, \\ Bukit Jimbaran Campus, Bali, Indonesia
}

\begin{abstract}
Despite the high number of victims every year, Physalia physalis's envenomations in Indonesia are scientifically unsounded. This annual event occurred mainly in Java's southern beaches and the Eastern Bali Islands, which are the most tourist destinations. The lack of scientific reports can lead to unaware and uneducated beachgoers resulting in a high number of victims, which in turn may ruin the economic sectors. Thus, this study aimed to report P. physalis's envenomation and its treatments in the southern beaches of the Special Region of Yogyakarta Province. It was based on the 15 beach lifeguards' and the primary health care units' reports in 2019-2020. The envenomation cases varied among beaches and years, whereas the highest number of cases were reported in the most popular beach (Parangtritis beach). The partial beach closing due to the pandemic COVID-19 caused the number of cases in 2020 was slightly lower than that in 2019. The envenomations' general symptoms were oedema and local pain that were treated with $5 \%$ food vinegar and hot water, if available. The severe cases (dyspnoea, nausea, vomiting, and cephalgia) were only reported twice in 2019. They were hospitalised in primary health care units; however, many people still practise the traditional non-scientific treatments, particularly in a chaotic situation.
\end{abstract}

(Int Marit Health 2021; 72, 2: 110-114)

Key words: Physalia physalis, envenomation, treatment, Indonesia

\section{INTRODUCTION}

Physalia physalis is a cosmopolitan organism found in many subtropical and tropical Atlantic, Pacific, and Indian Oceans, though it is originally tropical [1]. It has a floatfilled gas (Pneumatophore) that navigates the drift direction with diameter varied (3-12 in) and a submersible tentacle that can reach up to $30 \mathrm{~m}$ [2]. The Pneumatophore is bluish, whereas all the submersible parts are turquoise blue. $P$. physalis belongs to class Hydrozoa of Phylum Cnidaria. It comprises polyps with a specialized function [3]; they are pneumatophore, dactylozooids (tentacles) to catch the prey, and produce nematocysts, gastrozooids for food digestion, and gonozooids for reproduction. The preys are mainly fish and fish larvae $[4,5]$. The nematocyst produces a toxin that can paralyze fish [6]. Studies showed that the extract toxin of nematocyst in fish tissues caused nervous system respiratory centres, therefore caused general paralysis and death if the doses increased [7]. The envenomation to humans mostly occurs when the unaware or uninformed individuals contact this organism, especially children, due to their curiosities [8, 9]. The general symptoms when contact with human skin are the oedematous and skin inflammation $[8,10-12]$, followed by intense pain and burning sensation. More severe and fatal envenomations can cause vomiting, nausea, respiratory failure [13], and even death [14]. The envenomations cases of $P$. physalis were reported around the world, such as Brazil [8], Venezuela [11], Florida Atlantic coast [14], Chile [15], France [16], New Zealand [17], and Australia [18]. However, the reports from tropical Indo-Pacific remains limited. In Indonesia, the envenomation cases 


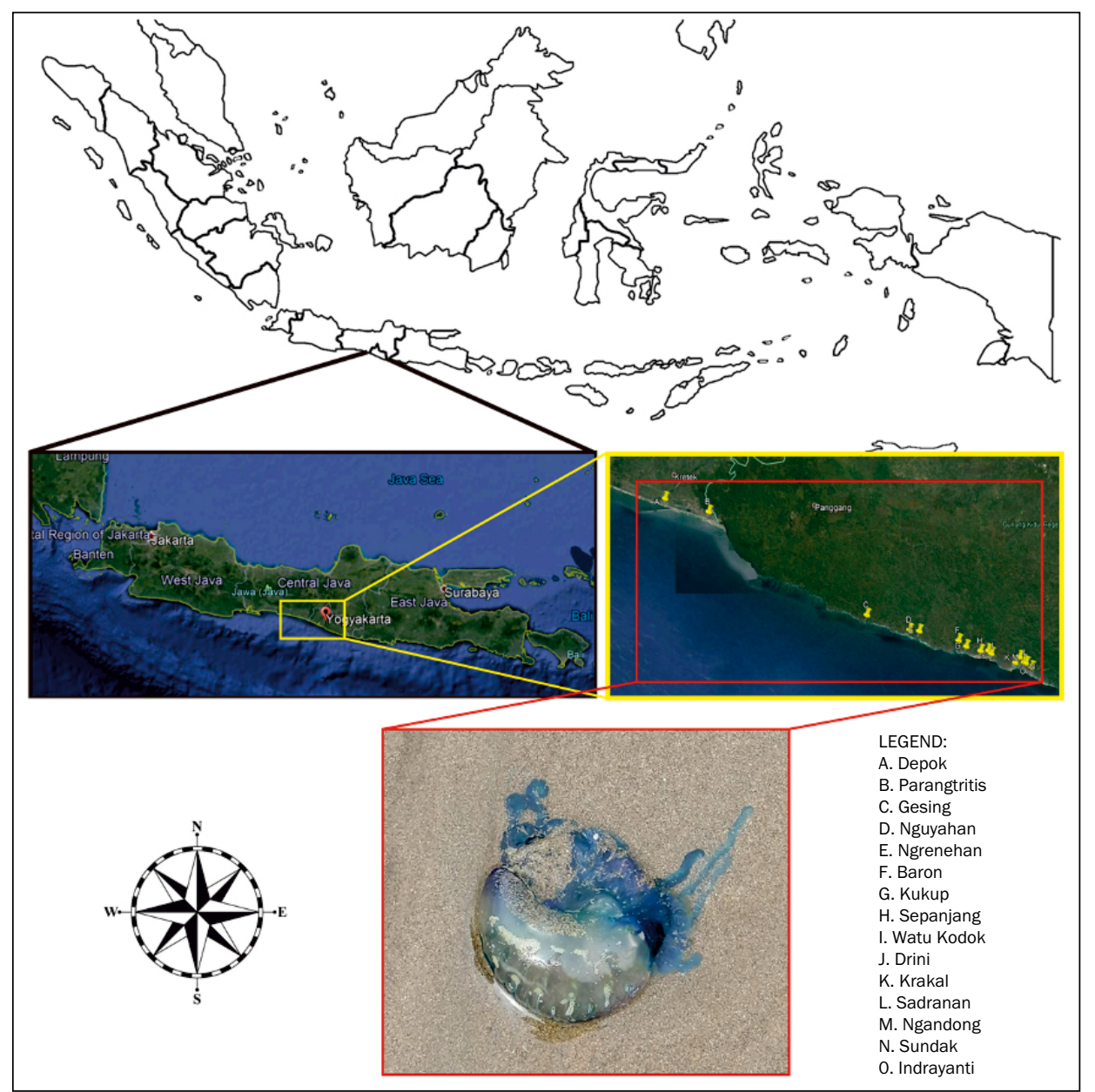

Figure 1. Relative location of Special Region of Yogyakarta Province, Indonesia, indicating the beaches where the P. physalis's envenomation occurred (insert: a specimen captured on the beach)

have been published in local and national newspapers since 2005, with the highest numbers found on the southern coast of Java and eastern coast of Bali islands, the most popular tourist destinations in Indonesia. It is annual events that reach tens to hundreds of people per year. $P$. physalis is commonly found stranded on the beaches from June to August, although in some places it was reported to be present until September. The reported cases mainly come from the beach lifeguards and the primary health care unit near the beaches. Few beach lifeguards have trained to apply first aid to the victims, such as vinegar and hot water immersion. However, they often did not practiced first aid, mostly when the victim numbers were massive; therefore, they also used any traditional treatments to control the chaotic situation. Despite the lack of age reported, the high number of cases every year that is mostly young children indicates the lack of information and education to the beach lifeguards and beachgoers as well as the absence of official authority's concern. Thus, to increase public awareness, this study aimed to report the
$P$. physalis envenomation and treatments in southern beaches of the Special Region of Yogyakarta Province based on the beach lifeguards and primary health care unit reports.

\section{PARTICIPANTS}

The participants in this research were mainly visitors to each beach that having stranded $P$. physalis.

\section{MATERIALS AND METHODS}

The local and national news have reported $P$. physalis's envenomations in Indonesia since 2005; however, the detailed information has been recorded since 2019. The envenomation cases per day were derived from the reports of 15 beach lifeguards, whereas the clinical features and course data were obtained from the primary health care unit's reports near the beaches in the Special Region of Yogyakarta Province, Indonesia, in 2019-2020 (Fig. 1). The identification of $P$. physalis was based on peculiar physical characteristics specimen found on the beaches. 


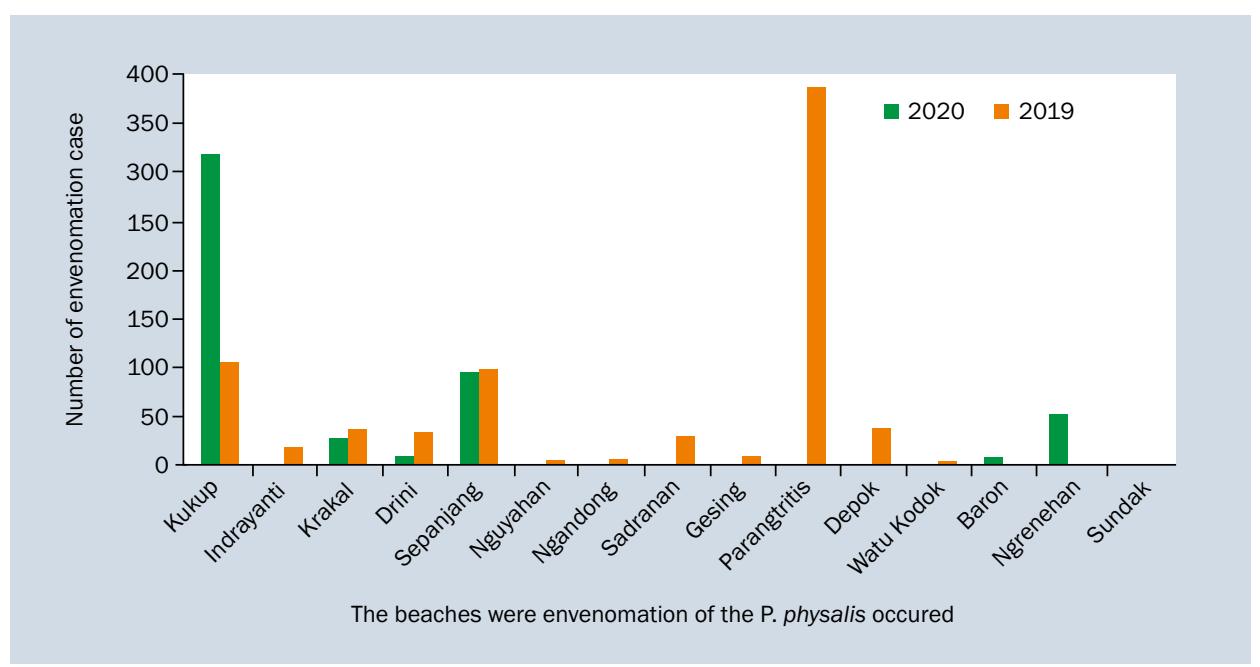

Figure 2. Number of the $P$. physalis's envenomation cases among beaches and year

Table 1. Characteristics of $P$. physalis's envenomations reported in the 15 beaches of Special Region of Yogyakarta Province, Indonesia in 2019-2020

\begin{tabular}{lll}
\hline P. physalis's & Year & \\
\cline { 2 - 3 } envenomations & $\mathbf{2 0 1 9}$ & $\mathbf{2 0 2 0}$ \\
\hline Period of year & June-July & June-July \\
Patients (number) & 773 & 514 \\
Patients (sex-ratio: male/female) & Not available & 1.44 \\
Clinical feature & Dyspnoea, nausea, vomiting, pain, cephalgia, & Pain, oedema: 514 (100\%) \\
Medical management & oedema: 2 (0.25\%) & \\
Clinical course & Hospitalisation, local treatment & Hospitalisation, local treatment
\end{tabular}

This research is a retrospective case series and describes the experiences reported by the 15 beach lifeguards and the primary health care unit's near the beaches in the Special Region of Yogyakarta Province, Indonesia, in 2019-2020.

\section{RESULTS}

The number of envenomation cases varied among beaches and years (Fig. 2), whereas the highest number of cases were reported in Parangtritis beach (more than 350 cases), followed by Kukup beach. The total number of cases in 2020 was lower than that in 2019; however, the envenomation cases in 2020 reached 0.67 fold of 2019's cases only in 17 days (total cases in 2019 reported from 34 days) (Table 1). Despite the closed beaches due to pandemic in 2020, two beaches (Krakal and Sepanjang) showed no significant differences in the envenomation cases in 2019 and 2020.

The envenomation reports and treatments of the P. physalis are shown in Table 1 . The sex ratio in 2020 indicated that the male patients were slightly predominant
(1.44); unfortunately, there is no available data in 2019. The general clinical features were a combination of pain and oedema that were dominantly found in all envenomation cases in 2019 and 2020, with pain scores ranging from 2 to 8 . Dyspnoea, nausea, vomiting, and cephalgia were rarely reported, in 2 cases only in 2019. The clinical course presented in this envenomation was a dermal mark (Fig. 3). Symptomatic treatment and topical first aid was conducted by spraying with $5 \%$ food vinegar and immersion with hot water, if available. This method was applied to over $90 \%$ of patients. The severe envenomation victims were treated in the primary health care units near the beaches. It was reported that up to $10 \%$ of the patients must have been hospitalised for 3 days to 1 week.

\section{DISCUSSION}

The low total number of envenomation cases in 2020 might be due to the pandemic of coronavirus disease 2019 (COVID-19), leading to partial beach closure announced by the local government of Special Region of 


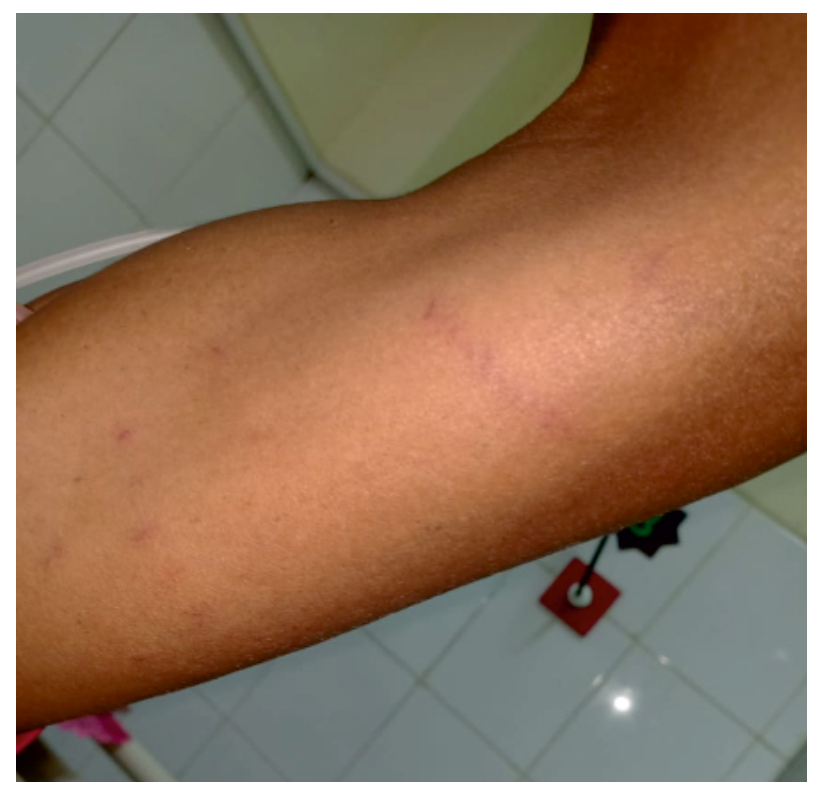

Figure 3. Clinical finding (dermal mark) related to $P$. physalis's envenomation. Photograph: Tri Maharani

Yogyakarta Province, particularly the most popular tourist destination beaches such as Parangtritis beach. Thus, tourists mainly visited the unpopular beaches other than the Parangtritis beach, such as Krakal and Sepanjang beaches, and having the annual stranded $P$. physalis at the same time. The hydro-oceanography of the southern seas of Java Island, which have high waves, makes them dangerous to swim. The envenomations mainly occurred when the beachgoers touched or took the stranded jellyfish while playing or walking on the beach (unrecorded data). These envenomation cases differ from those in other parts of the world where more than $50 \%$ are envenomated during bathing, diving, or swimming $[8,11,19]$. Moreover, despite the lack of age data, the beach lifeguards reported that the victims were mainly young children. They were attracted by distinctive colour and the bottle like-shape of the pneumatophore of the $P$. physalis that scattered abundantly on the beaches. The study showed that the dead $P$. physalis' nematocyst is still able to sting [20].

The first aid training to the jellyfish's envenomation has been conducted voluntarily by Toxinology Society of Indonesia (TSI) and Remote Envenomation Consultancy Services (RECS) Indonesia since 2013 to few beach lifeguards in the Special Region of Yogyakarta Province. Besides the training, socialisation was also carried out by put pamphlets in some areas. First aid treatment included the application of $5 \%$ food vinegar (affordable to get), hot water immersion, and modern dressing to the sting body parts, as recommended by the National Agency of Drug and Food Control (BPOM) [21]. Even though the effectiveness of the vinegar for $P$. physalis's envenomation remains debatable [10], the im- mersion of hot water was usually not practiced, particularly when the victims were massive. The application of vinegar is widely used in $P$. physalis's envenomation cases, such as in Brazil [8] and Venezuela [11]. The vast areas and a limited number of lifeguards on each beach relative to the high number of victims, predominantly young children, mostly made a chaotic situation. Therefore, the trained beach lifeguards also used traditional treatments such as tobacco, toothpaste, salt, ethyl chloride, and even urinated at the stung skin they believe are as effective as the first aid. Though those treatments are not scientifically proved [22].

The medical management of the envenomation of the $P$. physalis varied depending on the severity. According to the beach lifeguards' experiences, the local symptoms disappeared a few hours after treatment with the food vinegar. In severe cases with dyspnoea, nausea, vomiting, or cephalgia, the patients were treated with analgesic and antiemetic drugs. Due to dyspnoea, adequate airway and breathing management was needed to help the patient. The dermal mark due to $P$. physalis's envenomation had hyperaemia and moderate local pain. These signs and symptoms lasted 1 to 3 days. The envenomation symptoms in Indonesia were relatively milder than those in Brazil [8, 12], Venezuela [11], and France [19] that most frequently had local signs such as erythema, urticaria with linear plaques as well as a distinctive dermal scar. However, the general symptoms of $P$. physalis's envenomation in Indonesia were similar to those cases, without any fatal case. It was argued that adequate first aid and treatment and rehabilitation resulted in patients' recovery from $P$. physalis's envenomation. As human's curiosity and unawareness mainly contributed to $P$. physalis's envenomation, thus proper education to the beachgoers is the most important way to minimise the number of victims. Furthermore, the trained beach lifeguards and well equipped first aid will reduce the severity of the envenomation. Ultimately, it is suggested that the responsible authorities and government close the beach during $P$. physalis's annual stranding season since this envenomation would adversely affect the community health and the economic sectors.

\section{CONCLUSIONS}

The highest number of envenomation cases generally occurred in the most popular beach. The local government's partial beach closing due to the COVID-19 pandemic caused the cases in 2020 was slightly lower than those in 2019. Few beach lifeguards had been trained to treat the envenomations' general symptoms with $5 \%$ food vinegar and hot water, if available. Oedema and local pain were mainly reported as the general symptoms, whereas the severe cases were dyspnoea, nausea, vomit, and cephalgia, which only reported 2 cases in 2019 . They were treated 
with analgesic and antiemetic drugs and hospitalised for dyspnoea in the primary health care units. The combination of accurate education to the beachgoers and the trained beach lifeguards will reduce the severity of the $P$. physalis's envenomation.

\section{ACKNOWLEDGEMENTS}

The authors thank the beach lifeguards and the primary health care units of Special Region of Yogyakarta Province for the technical supports.

\section{REFERENCES}

1. Kirkpatrick PA, Pugh PR. (Eds.). Siphonophores and velellids: keys and notes for the identification of the species. Vol. 29. Brill Archive, 1984.

2. Munro C, Vue Z, Behringer RR, et al. Morphology and development of the Portuguese man of war, Physalia physalis. Sci Rep. 2019; 9(1): 15522, doi: 10.1038/s41598-019-51842-1, indexed in Pubmed: 31664071.

3. Hechtel G. A Synopsis of the Siphonophora. Totton AK, Bargmann HE. Quarterly Rev Biol. 1967; 42(1): 68-68, doi: 10.1086/405289.

4. Purcell JE. Predation on fish larvae by Physalia physalis, the Portuguese man of war. Mar Ecol Prog Ser. 1984; 19: 189-191, doi: 10.3354/meps019189.

5. Purcell JE. Feeding ecology of Rhizophysa eysenhardti, a siphonophore predator of fish larvae. Limnol Oceanogr. 1981; 26: 424-432.

6. Mackie GO, Boag DA. Fishing, feeding and digestion in siphonophores. Pubbl Statz Zool Napoli. 1963; 33: 178-196.

7. Lane $\mathrm{C}$, Dodge $\mathrm{E}$. The toxicity of physalia nematocysts. Biol Bull. 1958; 115(2): 219-226, doi: 10.2307/1539027.

8. Bastos DM, Haddad Junior V, Nunes JL. Human envenomations caused by Portuguese man-of-war (Physalia physalis) in urban beaches of São Luis City, Maranhão State, Northeast Coast of Brazil. Rev Soc Bras Med Trop. 2017; 50(1): 130-134, doi: 10.1590/0037-86820257-2016, indexed in Pubmed: 28327816.

9. Neves R, Amaral F, Steiner A. Levantamento de registros dos acidentes com cnidários em algumas praias do litoral de Pernambuco (Brasil). Ciên Saúde Colet. 2007; 12(1): 231-237, doi: 10.1590/ s1413-81232007000100026.

10. Haddad Junior V, Silveira FL, Migotto AE. Skin lesions in envenoming by cnidarians (Portuguese man-of-war and jellyfish): etiology and severity of accidents on the Brazilian coast. Rev Inst Med Trop Sao Paulo. 2010; 52(1): 47-50, doi: 10.1590/s003646652010000100008 , indexed in Pubmed: 20305955.
11. Cazorla-Perfetti DJ, Loyo J, Lugo L, et al. Epidemiology of the Cnidarian Physalia physalis stings attended at a health care center in beaches of Adicora, Venezuela. Travel Med Infect Dis. 2012; 10(5-6): 263-266, doi: 10.1016/j.tmaid.2012.09.007, indexed in Pubmed: 23067562.

12. Haddad Junior V, Virga R, Bechara A, et al. An outbreak of Portuguese man-of-war (Physalia physalis - Linnaeus, 1758) envenoming in Southeastern Brazil. Rev Soc Bras Med Trop. 2013; 46(5): 641-644, doi: 10.1590/0037-8682-1518-2013, indexed in Pubmed: 23904083.

13. Burnett JW, Calton GJ, Burnett JW, et al. Jellyfish envenomation syndromes. J Am Acad Dermatol. 1986; 14(1): 100-106, doi: 10.1016/s0190-9622(86)70013-3, indexed in Pubmed: 2869072.

14. Stein M, Marraccini J, Rothschild N, et al. Fatal portuguese man-o'war (Physalia physalis) envenomation. Ann Emerg Med. 1989; 18(3): 312-315, doi: 10.1016/s0196-0644(89)80421-4.

15. Brito JL. Physalia physalis (Linnaeus, 1758) (Cnidaria, Hydrozoa, Siphonophora) en la costa central de Chile. Not Mens Mus Nac Hist Nat. 2002; 349: 6-8.

16. Labadie M, Lambrot AL, Mangwa F, et al. Collective envenomation by Physalia physalis on the French Atlantic Coast. Clin Toxicol. 2010.

17. Slaughter RJ, Beasley DM, Lambie BS, et al. New Zealand's venomous creatures. N Z Med J. 2009; 122(1290): 83-97, indexed in Pubmed: 19319171.

18. Fenner PJ, Williamson JA. Worldwide deaths and severe envenomation from jellyfish stings. Med J Aust. 1996; 165(11-12): 658-661, doi: 10.5694/j.1326-5377.1996.tb138679.x, indexed in Pubmed: 8985452.

19. Labadie M, Aldabe B, Ong N, et al. Portuguese man-of-war (Physalia physalis) envenomation on the Aquitaine Coast of France: an emerging health risk. Clin Toxicol (Phila). 2012; 50(7): 567-570, doi: 10.3109/15563650.2012.707657, indexed in Pubmed: 22780958.

20. Haddad Junior V, Pardal PP, Cardoso Joo, et al. The venomous toadfish Thalassophryne nattereri (niquim or miquim): report of 43 injuries provoked in fishermen of Salinópolis (Pará State) and Aracaju (Sergipe State), Brazil. Rev Inst Med Trop Sao Paulo. 2003; 45(4): 221-223, doi: 10.1590/s0036-46652003000400009, indexed in Pubmed: 14502351.

21. Buku Pedoman Penatalaksanaan Keracunan. Jakarta: BPOM; 2016.

22. Wilcox CL, Headlam JL, Doyle TK, et al. Assessing the efficacy of first-aid measures in Physalia sp. Envenomation, using solutionand blood agarose-based models. Toxins (Basel). 2017; 9(5), doi: 10.3390/toxins9050149, indexed in Pubmed: 28445412. 